\title{
1 Recent Craton Growth by Slab Stacking Beneath Wyoming
}

3 Eugene D. Humphreys (corresponding author)

4 Department of Geological Sciences

51272 University of Oregon

$6 \quad$ Eugene, OR 97403-1272

$7 \quad 5413465575$

$8 \quad 5413464692$ (Fax)

9 genehumphreys@gmail.com

10

11 Brandon Schmandt

12 Department of Earth and Planetary Science

13 The University of New Mexico

14 Albuquerque, NM 87131

15 bschmandt@unm.edu

16

17 Maximiliano J. Bezada

18 Department of Earth Sciences

19 University of Minnesota

20310 Pillsbury Drive SE

21 Minneapolis, MN 55455-0231

$22 \quad$ mbezada@umn.edu 
24 Jonathan. Perry-Houts

25 Department of Geological Sciences

$26 \quad 1272$ University of Oregon

27 Eugene, OR 97403-1272

28 jperryh2@uoregon.edu 
29 Seismic tomography images high-velocity mantle beneath the Wyoming craton extending to

$30>250 \mathrm{~km}$ depth. Although xenoliths and isostatic arguments suggest that this mantle is depleted

31 of basaltic component, it is not typical craton: its NE elongate shape extends SW of the

32 Wyoming craton; xenoliths suggest that the base of Archean mantle was truncated from $\sim 180$ -

33200 to $\sim 140-150 \mathrm{~km}$ depth since the Devonian, and that the deeper mantle is younger than $\sim 200$

34 Ma. The Sevier-Laramide orogeny is the only significant Phanerozoic tectonic event to have

35 affected the region, and presumably caused the truncation. Apparently, the base of the Wyoming

36 craton was removed and young, depleted mantle was emplaced beneath the Wyoming craton

37 during the Sevier-Laramide orogeny. We suggest that the Wyoming craton experienced a $\sim 75$

38 Ma phase of growth through a three-stage process. First, flat-slab subduction removed 40-50 km

39 off the base of the Archean Wyoming craton. This was followed by emplacement of basalt-

40 depleted ocean plateau mantle lithosphere of the Shatsky Rise conjugate, which arrived in the

41 early Laramide. The geologic recorded of vertical motion in the Wyoming region suggests that

42 the plateau's crust escaped into the Earth's interior at 70-75 Ma. Initiation of Colorado Mineral

43 Belt magmatism at this time may represent a slab rupture through which the ocean crust escaped.

45 Keywords:

46 Wyoming craton, Shatsky conjugate, tomography, Laramide, Sevier, Colorado Mineral Belt

\section{Introduction}

Archean cratons of continents are stabilized and protected from tectonic and magmatic

51 disruption by their highly viscous, basalt-depleted mantle lithosphere whose thermal negative 
52 buoyancy is balanced by their compositional buoyancy (Jordan, 1978). The basis for this

53 understanding is provided by seismic observations and isostatic arguments, and by xenolith

54 samples of this mantle. However, the origin of the depleted mantle is not agreed upon, with three

55 primary hypotheses being considered (Arndt et al., 2009; Lee et al., 2011, Snyder et al., 2014).

56 Most prominent among these is the "slab stacking" hypothesis, in which subducted slabs of

57 Archean ocean lithosphere under-accrete the continent. Alternatives include an origin as plume

58 heads and as mantle depleted below volcanic arcs. In all these hypotheses a question arises as to

59 the whereabouts of the basaltic complement to the depleted mantle (Arndt et al., 2009). For the

60 plume and volcanic arc hypotheses, a common suggestion is eruption and erosion of the basalt.

61 For slab stacking - where the basaltic oceanic crust would have transformed to eclogite $-\mathrm{a}$

62 sinking of the dense eclogite into the asthenosphere is required.

63 This paper addresses the well-studied Wyoming craton. As a result of USArray seismic

64 coverage, it is among the best-imaged cratons, and it is unusual for having experienced recent

65 and significant modification. As a consequence of this modification it stands high, and it

66 provides xenolith sampling of its structure at times both before and after this modification. The

67 record created by this relatively young activity sheds light on the processes of craton creation

68 and destruction.

69 A range of geophysical, geochemical and geologic evidence, discussed below, leads us to

70 suggest that the Wyoming craton experienced Sevier-to-Laramide-age basal erosion followed by

71 the emplacement of highly depleted oceanic mantle lithosphere. The geologically-recorded

72 history of vertical motions provides clues as to how the ocean crust was lost during this young

73 slab-stacking event. 


\section{Geologic History}

The Wyoming craton was created by addition of Neoarchean volcanic arcs to a continental core of Paleoarchean to Mesoarchean age (Chamberlain et al., 2003). Then, through a rapid succession of amalgamation events at $\sim 1.8 \mathrm{Ga}$, this craton was added to the southern margin of

80 the North American shield and placed deep within the continental interior by south-side terrane

81 accretion (Whitmeyer and Karlstrom, 2007). Through the Proterozoic and until the late

82 Cretaceous the Wyoming craton remained stable (Blackburn et al., 2012). Wyoming subsided

83 slowly and, in a series of transgressions and regressions, was covered by a westward thickening

$84 \quad 1.5-3 \mathrm{~km}$ of sediment (Peterson, 1988) deposited in shallow seas and broad flood plains. The late

85 Paleozoic orogeny responsible for the Ancestral Rockies created major mountains and basins

86 within the Proterozoic crust south of Wyoming, but left the Archean crust nearly unaffected

87 (Erslev and Koenig, 2009). Another layer of sediment was deposited in the Cretaceous Interior

88 Seaway, starting $\sim 100 \mathrm{Ma}$ and covering most of Wyoming with $1.5-5 \mathrm{~km}$ of sediment (Molenaar

89 and Rice, 1988; Scott et al., 2009; Liu et al., 2011; Cook and Bally, 1975). Seaway subsidence is

90 attributed to dynamic suction associated with a shallowing of Farallon slab dip (Mitrovica et al.,

91 1989; Spasojevic et al., 2009). Unusually thick deposits were laid down in westernmost

92 Wyoming, NW Colorado and eastern Utah (Roberts and Kirschbaum, 1995; Liu et al., 2011,

93 Chapin, 2012) as a combined result of flexural downwarping driven by the $\sim$ east-verging Sevier

94 overthrust system (DeCelles, 2004) and a more regional dynamic suction (Liu et al., 2011).

95 Then, with the first significant deformation in over a billion years, crystalline basement was

96 thrust over its sedimentary cover as Wyoming crust was shortened by 50-60 km (Bird, 1998)

97 during the Laramide orogeny ( 75-45 Ma, Dickinson et al., 1988). The accommodating thrust 
98 faults are distributed across Wyoming in a branch-like pattern that created closed and nearly

99 closed basins. Sediment was stripped from areas of high relief, often exposing crystalline

100 basement, and was deposited into the basins and then largely evacuated (McMillan et al., 2006).

101 Based on the occurrence of thrust faulting in the deep continental interior and the

102 termination of California arc volcanism at $\sim 80 \mathrm{Ma}$, the Laramide orogeny generally is attributed

103 to flattening of subducted Farallon slab against the base of North America (Coney and Reynolds,

104 1977; Saleeby, 2003). This is supported by the xenolith record, which suggests basal erosion of

105 cratonic western U.S. to depths of 135-150 km sometime between the Devonian and the Eocene

106 periods, presumably during the Sevier and Laramide orogenies (Li et al., 2008; Eggler et al.,

107 1988). The primary cause of slab flattening is thought to be subduction of the large ocean plateau

108 created as a conjugate to the Shatsky Rise (Livacccari et al., 1981; Saleeby, 2003). The

109 calculated path of the plateau takes it under southern California, the Colorado Plateau and

110 Wyoming (Liu et al., 2008). During this time the Colorado Plateau and Rocky Mountain region

111 began ascending to their current high elevations (Flowers et al., 2008; Karlstrom et al., 2012),

112 and the region became magmatically quiet except along the Colorado Mineral Belt.

113

\section{3. Mantle structure}

115

116 Our goal is to understand the origin of the deep part of the Wyoming craton, and we

117 make use of three approaches. Seismic tomography provides the best constraint on the shape of

118 thermal structure in this region. Isostatic calculations provide constraint on lithospheric density

119 and its time evolution, and when combined with the seismic constraints on temperature, it sheds

120 light on the degree of basalt depletion. Xenoliths sample the mantle to depths $\geq 170 \mathrm{~km}$ at a few 
121 locations, thereby providing information on composition and temperature at their time of

122 eruption. The time spanned by the xenolith eruptions supply information on lithospheric

123 evolution. We then consider our understanding of the deep Wyoming craton in the context of

124 Late Cretaceous subduction of the Shatsky conjugate and flat-slab subduction. Subduction of this

125 ocean plateau provides both a source of depleted mantle and a means for delivering it to the base

126 of the Wyoming craton.

127

\subsection{Mantle seismic structure}

Regional upper mantle structure has been imaged well with both surface waves and body

131 waves. We use the Rayleigh-wave tomography of Shen et al. (2013; online download), which

132 they inverted jointly with receiver-functions to constrain Moho depth. Fig. 1 shows this model in

133 our study area. To make these figures, we remove the mean velocity of each layer and divide the

134 result by the average S-wave velocity for that layer to obtain a layer-wise velocity perturbations

135 that can be compared to the body-wave tomography. The surface-wave model images a $400-\mathrm{km}$

136 wide high-velocity $\left(\mathrm{V}_{\mathrm{S}}=4.65-4.8 \mathrm{~km} / \mathrm{s}\right.$; in Fig. $1, \delta \mathrm{V}_{\mathrm{S}}>3 \%$ fast $)$ structure extending SW-NE

137 across Wyoming and extending from $\sim 60$ to $180 \mathrm{~km}$ in depth. The deeper parts of this model are

138 not well resolved: the published model extends to $150 \mathrm{~km}$ depth - considered a depth that is

139 reliably resolved - whereas the online version provides the entire $200 \mathrm{~km}$ depth extent of the

140 model. The NE-trending high-velocity mantle structure beneath Wyoming is the only major

141 high-velocity upper-mantle structure imaged with surface waves west of the Great Plains. We

142 associate the deep parts of this structure with the Shatsky conjugate. 
The teleseismic P-wave tomography provides the best resolution on the deeper structure.

144 We use the model of Schmandt and Humphreys (2010, Fig. 1). Resolution of body-wave

145 tomography diminishes at depths above the average station spacing, which for our data is $\sim 70$

$146 \mathrm{~km}$. For deeper structure, relatively high resolution is achieved through the use of abundant data

147 recorded over a broad area. Inversion also makes use of finite-frequency sensitivity kernels,

148 although at the highest frequencies $(\sim 1 \mathrm{~Hz})$ used for arrival-time estimation (by cross

149 correlation), finite-frequency effects are of little significance. Lower frequency measurements

150 are also included to reduce the reliance on regularization to stabilize the inversions and obtain

151 smooth images. Resolution tests indicate that lateral and depth resolution is excellent over the

$152 \quad 75-700 \mathrm{~km}$ depth range, with only minor amplitude degradation of the model amplitude at each

153 node (Fig. S1). Visually there is little degradation of the input image. Synthetic resolution tests,

154 however, do not address artifacts created by effects that are not included in the test (including

155 seismic anisotropy, ray-path deviation from that in a 1-D Earth, and structure of scale smaller

156 than our node spacing). Considering these limitations, the actual uncertainty in the imaged

157 structure is greater than that represented by the resolution tests, and resolution estimation

158 becomes somewhat subjective. Two lines of reasoning suggest that the actual resolution of the P-

159 wave model is good across the upper mantle.

160 Frist, when the body- and surface-wave models are compared, it is clear that the two

161 tomographic techniques image similar structure over the $75-160 \mathrm{~km}$ depth range where

162 resolution is good in both models. The average amplitudes of the S-wave anomalies are about

163 twice that of the P-wave anomalies, as is common (Schmandt and Humphreys, 2010, found

$164 \mathrm{~d} \ln \mathrm{Vp} / \mathrm{d} \ln \mathrm{Vs}=1.8$ for the western U.S.). The main difference seen in the body- and surface-wave

165 images over this depth range is the presence in the body-wave images of shorter wavelength 
166 lateral structure, as expected for inversions based on teleseismic arrivals, whereas the surface-

167 wave model resolves shorter wavelength depth variation in structure. The similarity of results

168 between inversions using different data types with different sensitivities suggests that the imaged

169 structures are well resolved beneath our study area in the 75-160 km depth range. Below $160 \mathrm{~km}$

170 depth we rely solely on the teleseismic P-wave images. The excellent results from the resolution

171 tests at these depths indicate that there is sufficient ray-path coverage for good resolution. This,

172 in conjunction with the corroborated good resolution above $160 \mathrm{~km}$ depth, is a strong indication

173 that resolution based on the P-wave images is good at greater depth. The second indication of

174 good body-wave resolution in the upper mantle of the Schmandt and Humphreys (2010) model is

175 that the imaged velocity variations near 410 and $660 \mathrm{~km}$ depth correspond well with imaged

176 deflections in the 410 and $660 \mathrm{~km}$ discontinuities (Schmandt et al., 2012). As a result of these

177 two comparisons, we think that vertical resolution on major structures beneath Wyoming and

178 nearby environs across the $75-400 \mathrm{~km}$ depth range of interest here is $\sim 50 \mathrm{~km}$.

179 The NE-trending Wyoming structure is imaged extending to depths of $\geq 250 \mathrm{~km}$, with the

180 structure beneath NE Wyoming extending to greater depths. The main difficulty in assessing the

181 deepest reaches of this structure comes from the complications created by the presence of deeper

182 high-velocity structures in the region that are thought to be fragments of Farallon slab that

183 subducted since $60 \mathrm{Ma}$ (Liu and Stegman, 2011; Schmandt and Humphreys, 2010).

184 To conclude this section, it appears that a large volume of the Wyoming upper mantle is as

185 seismically fast and thick as other cratons. Since variations in mantle seismic velocity as great as

186 those imaged must represent significant temperature variations (Schutt and Lescher, 2006;

187 Cammarano et al., 2003, 2009), the steep sides of this structure indicate that it is not in thermal

188 equilibrium with the adjacent mantle and hence its form must be far younger than the Archean 
189 age of the overlying crust and uppermost mantle or maintained by active processes (Cooper et

190 al., 2004). We add that, when addressing the possible presence of Shatsky conjugate ocean crust,

191 results from receiver function imaging find no evidence for a preserved layer of a basaltic ocean

192 crust within this high-velocity body (Levander and Miller, 2012; Lekić and Fischer, 2013;

193 Hopper et al., 2014). If an oceanic crust had converted to eclogite, its seismic velocity would

194 make it difficult to image, so the presence of an eclogetic layer cannot be ruled out from seismic

195 velocity structure alone. Isostatic arguments, however, suggest that significant amounts of

196 eclogite are not present.

197

198 3.2 Mantle Xenoliths

200 Kimberlite eruptions at two well-studied sites brought mantle xenoliths to the surface from

201 depths $>150 \mathrm{~km}$ (Fig. 2a). The southern site erupted during the Devonian, well prior to the

202 Sevier-Laramide orogeny, and the northern site erupted during the early Eocene, shortly after

203 this orogeny. Since the only significant tectonic event to affect this region between these two

204 eruptions was the Sevier-Laramide orogeny, these xenolith suites afford an opportunity to infer

205 how this orogeny modified the mantle lithosphere (Eggler et al., 1988; Carlson et al., 1999). The

206 southern site erupted through Proterozoic crust just south of the Wyoming craton. These samples

207 define a cool Devonian geotherm (Eggler et al., 1988, Ashchepkov et al., 2013), originate from

208 depths as great as $\sim 200 \mathrm{~km}$ (Eggler et al., 1988), and incorporate Archean xenoliths from the

209 greatest depths (Schulze et al., 2008). That is, these xenoliths define a Devonian craton of typical

210 age, thickness and thermal structure (Artemieva, 2009) (Fig. 2b). 
The northern site is exposed in the northernmost Wyoming craton near the Great Falls

212 tectonic zone (Fig. 2a). Two xenolith populations are found there. A "low-temperature" suite

213 defines a cool pre-eruptive geotherm (of $\sim 40 \mathrm{~mW} / \mathrm{m}^{2}$, Hearn, 2004) to depths of $\sim 130 \mathrm{~km}$

214 (Hearn, 2004) to $140 \mathrm{~km}$ (Eggler et al., 1988) (Fig. 2b) typical of a craton (Artemieva, 2009),

215 and these xenoliths are of Archean age (Carlson et al., 2004). Xenoliths from greater depth, the

216 "high-temperature" suite, are about as depleted as the low-temperature suite (Carlson et al.,

217 1999; Carlson et al., 2004), but they are younger than a few hundred million years in age

218 (Carlson et al., 1999; Carlson et al., 2004) and record temperatures $\sim 200-300^{\circ} \mathrm{C}$ above that

219 defined by the Archean geotherm (Hearn, 2004) (Fig. 2b). These samples come from depths

220 estimated to cover the range $150-200 \mathrm{~km}$ (Eggler et al., 1988) or 130-170 km (Hearn, 2004).

221 The common explanation for these findings is that Laramide-age flat-slab subduction truncated

222 the craton base near $150 \mathrm{~km}$ depth, and that the deeper lithosphere is young, depleted peridotite

223 of an undetermined origin (Eggler et al., 1988; Carlson et al., 1999, Carlson et al., 2004). The

224 downward extrapolation of the Archean geotherm intersects the mantle solidus at $200 \pm 30 \mathrm{~km}$

225 (Fig. 2b), implying that prior to its (young, presumed Laramide) truncation, this lithosphere had a

226 craton-like thickness and thermal structure similar to that resolved in the southern (Devonian)

227 site (Eggler et al., 1988). The only simple explanation for these xenoliths is the removal of the

228 Archean lithosphere from a depth of $\sim 170-200 \mathrm{~km}$ to a depth of $\sim 130-150 \mathrm{~km}$, followed quickly

229 by the emplacement of young depleted mantle that experience temperatures of $\sim 1250-1450^{\circ} \mathrm{C}$

230 (Hearn, 2004) but was cool when it was emplaced against the overlying Archean lithosphere (to

231 account for both its high seismic velocity and the preserved cool Archean geotherm). The

232 location of this xenolith site is north of the deep high-velocity mantle structure that we associate 
233 with the Shatsky conjugate, suggesting to us that the deep xenoliths from the northern site

234 sampled more typical Farallon ocean lithosphere adjacent to the Shatsky conjugate.

235 Although the two well studied deep-sampling xenolith sites are far from one another and lie

236 on the edges of the Wyoming craton, the fact that the Colorado site was cool and $\sim 200 \mathrm{~km}$ thick

237 during the Devonian eruptions, and the Montana site was cool (and therefore thick) shortly

238 before the Eocene eruptions, seems to indicate the presence of a pre-Sevier-Laramide craton root

239 extending to $\sim 200 \mathrm{~km}$ beneath each site and, reasonably, beneath the intervening Archean craton

240 as well. At present, the base of Archean North America occurs at a depth of $\sim 130-150 \mathrm{~km}$

241 beneath central Montana (Eggler et al. 1988; Hearn, 2004). The other well-studied location

242 where xenoliths define the post-Laramide base of the lithosphere is the Paleoproterozoic

243 lithosphere of the central Colorado Plateau. There, the base occurs at a depth of $\sim 135-140 \mathrm{~km}$

244 (Smith, 2010; Li et al., 2008). Assuming that lflat-slab subduction was the cause of North

245 America basal erosion (e.g., Li et al., 2008; Smith, 2010), the xenolith samples suggest that

246 Laramide-age erosion removed basal North America lithosphere to depths of $135-150 \mathrm{~km}$.

$248 \quad 3.3$ Isostasy

Wyoming's current elevation of 1.2-2.3 km is unusually great for cratonic lithosphere. If

251 one were to estimate its elevation using a simple Airy isostatic calculation, the crustal thickness

252 of Wyoming yields an elevation that is 1-2 km lower than that observed (Fig. S2). This implies a

253 relatively buoyant mantle lithosphere. However, our interest in mantle density structure is not

254 addressed well with this calculation since it does not incorporated information on other sources

255 of lateral density variations that are known to be present (e.g., Gilbert, 2012; Levandowski et al., 
2014), and addressing the mantle buoyancy structure in particular is made difficult because the

257 imaged structure is not the dominant factor dictating current-day topography in the region

258 (Gilbert et al., 2003; Becker et al., 2013; Levandowski et al., 2014). This presumably is because

259 the effects of cool temperatures (which largely creates the mantle seismic structure) are largely

260 offset by the compositional buoyancy of this Archean and Paleoproterozoic mantle (Jordan,

261 1988; Lee et al., 2011; Bailey et al., 2012; and the mantle xenoliths discussed in the preceding 262 section).

263 More insight is gained by comparing Wyoming's current elevation with its long-stable 264 elevation near seal level prior to incursion of the Cretaceous Seaway (Spencer, 1996). Across 265 most of the Rocky Mountains and Great Plains, the near-shore sediment of the Dakota Group 266 was the first to be deposited as a result of the encroaching Seaway. This deposition began $\sim 100$

267 Ma (Scott et al., 2009), usually unconformably upon pre-Cretaceous rock. Because insignificant 268 amounts of sediment were deposited between 100-125 Ma, we choose $125 \mathrm{Ma}$ as a reference 269 isostatic state. This time predates Seaway downwarping and the Sevier thrusting near the western 270 margin of our study area. We then assess dynamic topography and changes in crustal buoyancy 271 since that time to address changes in mantle lithosphere buoyancy. The results (Fig. 3) are 272 smoothed at a wavelength of $150 \mathrm{~km}$, roughly equivalent to the shortest flexural wavelength of 273 this lithosphere (Lowry and Perez-Gussinye, 2011). At wavelengths of $150 \mathrm{~km}$ and longer, the 274 primary crustal causes of increased surface elevation since $125 \mathrm{Ma}$ are found to be the addition 275 of Seaway sediment (accounting for up to $700 \mathrm{~m}$ of elevation), Laramide crustal thickening (up 276 to nearly $250 \mathrm{~m}$ of elevation), post-Laramide crustal heating (up to nearly $500 \mathrm{~m}$, Levandowski 277 et al., 2014), and possibly lower-crustal hydration (Jones et al., 2015). After removing the effects 278 of dynamic topography, sedimentation, erosion, crustal thickening and thermal expansion of the 
279 crust, we conclude that about $0.4-1.4 \mathrm{~km}$ of Wyoming's current elevation can be attributed to a

280 combination of increased mantle lithosphere buoyancy since $125 \mathrm{Ma}$ and lower crustal hydration 281 (Fig. 3i).

282

3.3.1. Current dynamic topography created by density structure below $200 \mathrm{~km}$ depth

284 We estimate current dynamic topography created by the density structure below $200 \mathrm{~km}$ 285 using the Becker et al. (2013) coding of the Hager and O'Connell (1981) algorithm for viscous

286 flow in a spherical Earth possessing only radial viscosity variations. Flow is driven by a density

287 structure inferred by scaling the global Smean S-wave seismic model (Becker and Boschi, 2002)

288 to density, using $\mathrm{d} \ln \rho / \mathrm{d} \ln \mathrm{V}_{\mathrm{S}}=0.2$ (Stixrude and Lithgow-Bertelloni, 2011). We find that

289 structure deeper than $200 \mathrm{~km}$ creates $73-50 \mathrm{~m}$ of dynamic subsidence (W-E) across our study

290 area (Fig. 3b), and dynamic subsidence remains insignificant with plausible variations in radial

291 viscosity structure. Considering that 125 Ma precedes the creation of the Cretaceous Seaway, we 292 assume no significant dynamic topography at $125 \mathrm{Ma}$

294 3.3.2. Elevation at $125 \mathrm{Ma}$

295 At $125 \mathrm{Ma}$, the regional landform across the Colorado Plateau, Rocky Mountains and Great 296 Plains was one of low elevation (Fig. 3c) and relief, with the former Ancestral Rockies having 297 been eroded to low hills and the highlands of the Sevier fold and thrust belt occupying what now 298 is the Basin and Range (Molenaar and Rice, 1988, Blakey and Ranney, 2008). The shoreline 299 crossed southern Wyoming with a shallow sea opening to the NNE (Blakey and Ranney, 2008;

300 Sloss, 1988), suggesting a reference isostatic state for Wyoming near the sea level at that time.

301 Fig. 3c shows our assumed initial elevation field, which we estimate from the 125 Ma paleo- 
geographic reconstruction of Blakey and Ranney (2008). The disturbance on the west side of the

303 area shown in Fig. 3 is the result of the early Sevier orogeny. Sea level at 125 Ma averaged about

$304150 \mathrm{~m}$ higher than its current level (Haq et al., 1988), so we add this amount to the elevation

305 estimated at $125 \mathrm{Ma}$.

306

\section{3.3.3. Post-125 Ma sedimentation and erosion}

308 Deposition of sediment after $125 \mathrm{Ma}$ elevated the surface by thickening the crust with low-

309 density rock. We use the sediment isopach maps of Cook and Bally (1975) for Eocene and older

310 deposits and McMillan et al. (2006) for younger deposits to infer net post-125 Ma sediment

311 thickness (averaged over rectangular areas one-degree on a side). Rock density of this spatially

312 varying sediment pile is estimated using the S-wave upper crustal model of Lin et al. (2014) and

313 Brocher's (2005) velocity-to-density scaling relations. A mantle density of $3300 \mathrm{~kg} / \mathrm{m}^{3}$ is

314 assumed in our isostatic calculations. Fig. 3d shows the smoothed estimate of the resulting

315 elevation gain. The major deep sedimentary basins are clearly visible.

316 To calculate the effects of the erosion of pre-125 Ma sediment from the Colorado Plateau

317 and the Laramide uplifts, we use Fan and Carrapa (2014) and Reed et al. (2005) to estimate the

318 amount of this sediment that was removed (again, averaging over areas one-degree on a side).

319 The pre-erosion thickness of this sediment is estimated by extrapolating the mapped sediment

320 thickness of the pre-125 Ma sediments Cook and Bally (1975). Sediment and mantle densities of

3212550 and $3300 \mathrm{~kg} / \mathrm{m}^{3}$, respectively, are assumed. Fig. 3e shows the combined effect on elevation

322 of sediment deposited since our reference date of $125 \mathrm{Ma}$, and of the erosion of sediment older

323 than $125 \mathrm{Ma}$. The erosion has a relatively minor overall effect, whereas post-125 Ma sediment

324 accumulation is important. The overall RMS value of elevation gain is $330 \mathrm{~m}$. 
3.3.4. Crustal thickening

327 Except for the Sevier-age thrusting in westernmost margin of Wyoming, the only

328 significant deformation in Wyoming occurred during the Laramide orogeny, and the amount of 329 shortening was modest. We use the net displacements calculated by Bird (1998), which covers

330 the time interval 40-80 Ma. From these displacements we calculate the strain field. To obtain

331 change in crustal thickness, we assume that the current crustal thickness (from Shen et al., 2013)

332 is created by straining an initial crust by the amount estimated from the Bird's displacement

333 field, and use the resulting thickness difference to calculate an isostatic uplift assuming an 334 average crustal density of $2700 \mathrm{~kg} / \mathrm{m}^{3}$ and a mantle density of $3300 \mathrm{~kg} / \mathrm{m}^{3}$. Small values are 335 obtained for crustal thickening, consistent with imaged crustal thickness variations, which show 336 no apparent correlation with the distribution of Laramide thrusting (Gilbert, 2012; Yeck et al.,

337 2014). The smoothed result is shown in Fig. 3f. At this level of smoothing, Rocky Mountain

338 uplifts are as great $\sim 200 \mathrm{~m}$, with a maximum uplift of $\sim 250 \mathrm{~m}$ occurring at the overthrust belt in 339 westernmost Wyoming.

\section{3.3.5. Crustal heating}

342 We use the values for crustal thermal uplift estimated by Levandowski et al. (2014) (Fig.

343 3g). This field is dominated by the heating in the Yellowstone area and across much of Colorado, 344 largely over the Rocky Mountain region. We assume that the initial thermal structure was 345 uniform over this cratonic region at $125 \mathrm{Ma}$, and that only warming has occurred to produce the 346 observed thermal structure. We also make a simple eastward extrapolation of the Levandowski et 
347 al. (2014) field from $-102^{\circ}$ to $-99^{\circ}$ in a smooth manner that follows the regional heatflow map

348 (Blackwell et al., 1991). Estimated thermal uplift for Wyoming is $200-400 \mathrm{~m}$.

\subsubsection{Summary of Isostasy}

Fig. $3 \mathrm{~h}$ shows the combined effects on elevation increase since 125 Ma resulting from all

352 crust and mantle contributions except those originating from a hydrated lower crust and from

353 buoyancy changes in the mantle lithosphere. Ignoring crustal hydration, Fig. 3i shows our

354 calculated increase in mantle lithosphere buoyancy since $125 \mathrm{Ma}$ (represented as surface uplift).

355 The result is a regional, long-wavelength uplift that increases from zero in the eastern Great

356 Plains of North and South Dakota to about $0.4 \mathrm{~km}$ in NE Wyoming and to about $1 \mathrm{~km}$ in western

357 Wyoming. In addition to this long-wavelength trend, there is a ridge of anomalous elevation

358 extending from the very slow mantle beneath Yellowstone to the Colorado Rocky Mountains. In

359 Wyoming, this ridge adds an additional $0.3-0.4 \mathrm{~km}$ of elevation. For comparison, the colored

360 circles in Fig. 3i shows the nearly identical uplift calculated by Spencer (1996) along a traverse

361 that crosses the Colorado Plateau, Colorado Rocky Mountains and the Great Plains. Also shown

362 on this figure is the elevation predicted by Jones et al. (2015) for uplift due to lower crustal

363 hydration. At least at the three sites discussed by Jones et al., their predicted uplift is equivalent

364 to our elevation anomaly (squares in Fig. 3i). Assuming that their estimated uplift calculations

365 are applicable across the Wyoming region, then it is possible that the mantle lithosphere in the

366 Wyoming area has about the same buoyancy now that it has had for hundreds of million years.

367 Across most of Wyoming the mantle is imaged to be of relatively high velocity (and hence

368 cool), extending in depth to 230-310 km (Fig. 1a). This mantle buoyancy has remained about

369 constant or increased since before the region was affected by the Sevier orogeny (Fig. 3i). 
370 However, the xenolith evidence from north-central Montana suggests that the mantle beneath

$371 \sim 150 \mathrm{~km}$ is young. The positive-to-neutral buoyancy of the deep high-velocity mantle (that we

372 attribute to the Shatsky conjugate) implies that it is more depleted than normal Phanerozoic

373 mantle. A plume origin and extraction of $\sim 20 \mathrm{~km}$ of basalt from the mantle during creation of the

374 Shatsky conjugate (Fig. S4) would create such highly depleted upper mantle. If the deep high-

375 velocity mantle does have its origin as the Shatsky conjugate, the inferred non-negative mantle

376 buoyancy precludes the presence of significant volumes of its eclogetic ocean crust.

\section{4. The Shatsky conjugate}

\subsection{Shatsky conjugate motion}

Most workers ascribe initial Sevier-Laramide slab flattening to the end-on subduction of 383 a large ocean plateau created as a conjugate to the Shatsky Rise (Livacccari et al., 1981; Saleeby, 384 2003) at the Pacific-Farallon-Izanagi triple junction (Nakanishi et al., 1999). The shape of the 385 Shatsky conjugate shown in Fig. 4 is made by reflecting the Shatsky Plateau about its short axis, 386 orienting this plateau in direction of Farallon spreading at time of its creation, and removing the 387 Ori volcanic construction on its NW side (being located west of the main volcanic trend, the 388 conjugate Ori probably would have been on the Izanagi plate, not the Farallon plate). The motion 389 of this plateau across the Pacific basin has been calculated from plate reconstruction models (Liu 390 et al., 2008), and assuming this plateau remained attached to the Farallon Plate, its subduction 391 would have begun $\sim 90-95$ Ma beneath southern California and follow a path similar to that 392 illustrated in Fig. 4 (Liu et al., 2008). 
By using the Shatsky Rise as a reference, the leading (oldest) part of the subducted

394 conjugate would have been comprised of 20-30 km of basaltic crust (Korenaga and Sager, 2012)

395 and its underlying basalt-depleted mantle. The initial volcanic construction on the Shatsky Rise

396 (the Tamu massif) is described as the world's largest volcano (Sager et al., 2013), suggesting that

397 the underlying mantle is the most depleted. Our ability to infer the shape of the Shatsky

398 conjugate from the Shatsky plateau is limited on its NE and NW sides (Fig. S3. This and

399 additional aspects of the reconstruction are provided in the Supplement.). This differs from its

400 SW margin, where the shape of the Shatsky conjugate was created adjacent to the Pacific plate

401 and its shape can be inferred from the Shatsky Rise.

The high-velocity Wyoming mantle deeper than $140 \mathrm{~km}$ is located near where Liu et al.

403 (2008) place the Shatsky conjugate at $\sim 64 \mathrm{Ma}$ (Fig. 4), and its shape is similar to the inferred

404 shape of this plateau. The most prominent and deepest part $(>250 \mathrm{~km})$ of the imaged high-

405 velocity Wyoming mantle structure lies beneath NE Wyoming. Being on the leading (NE) end of

406 the high-velocity structure, we associate this with the conjugate Tamu volcanic center. We

407 modify the path estimated with plate reconstruction models (Liu et al., 2008) so that the Shatsky

408 conjugate is located beneath the imaged high-velocity structure and with the inferred conjugate

409 Tamu volcanic center positioned beneath the deepest high-velocity structure (Fig. 4). To make

410 this path, we move the Liu et al. path north $\sim 200 \mathrm{~km}$ and straighten out the predicted change in

411 transport direction at $\sim 80 \mathrm{Ma}$. These modifications are made to coordinate with the mantle image

412 and match the geologic observations discussed in the following section (especially the location

413 of the severely disrupted southern California crust described by Saleeby, 2003). Between these

414 two constraints the actual path of the Shatsky conjugate is not well constrained, and other

415 relatively minor variations to this path are possible. The positioning of the Shatsky conjugate 
416 shown in Fig. 4 is one in which the ocean plateau rotated $8^{\circ}$ clockwise so that the conjugate of

417 the large Shirshov volcanic construction correlates with the imaged high-velocity structure

418 beneath the SW Colorado Plateau. Levander et al. (2011) provide an interpretation of this high-

419 velocity feature that involves a downwelling "drip" of the North American lithosphere, and this

420 accounting does not require the Shatsky conjugate. We consider it possible that the deep part of

421 this mantle structure is the mantle complement to the conjugate of the Shirshov massif; it also is

422 possible that this high-velocity feature does not involve the mantle of the Shatsky conjugate at

423 all.

424

425

4.2 Fate of the Shatsky conjugate crust

426

427 An unusual origin for the high-velocity Wyoming mantle deeper than $\sim 150 \mathrm{~km}$ is implied

428 by its basalt-depleted composition and young age (inferred from nearby xenoliths and isostatic

429 modeling). The fortuitous arrival of mantle with these properties on the flat-subducting Farallon

430 slab makes ocean-plateau under-accretion an attractive option. However, the fate of the plateau's

431 ocean crust then becomes an outstanding problem. This crust subducted beneath southern

432 California, but seismic and isostatic evidence indicates that it is not present beneath Wyoming.

433 During transit beneath North America at depths of $\sim 140 \mathrm{~km}$ beneath the Colorado Plateau

434 (Smith, 2010; Li et al., 2008) and Wyoming (Egger et al., 1988; Hearn, 2004), the Farallon and

435 plateau basalt crust would eventually transform to eclogite. We use the geologically recorded

436 history of vertical tectonics to infer when and where this transformation occurred, and for the

437 subsequent fate of this crust. 
439 removed much of continental lithosphere beneath southern California (Saleeby, 2003; Luffi et

440 al., 2009), emplaced Pelona-type schists (Grove et al., 2003), and tectonically disrupted the

441 volcanic arc (Saleeby, 2003). Farallon mantle lithosphere is sampled beneath the Mojave Desert

442 with its crust presumably attached (Luffi et al., 2009), and basanite blocks are common in

443 exposed schist outcrops that probably are pieces of Farallon ocean crust (Jacobson et al., 2011).

444 If these are samples of Shatsky conjugate crust, they could account for some of the missing crust.

445 However, the volume of ocean crust that might reside beneath California is small compared to

446 that of the Shatsky conjugate crust. It appears that most of the Farallon oceanic crust, both off

447 and on the Shatsky conjugate, was transported east of California with the Farallon slab.

448 Beneath the Colorado Plateau, the 85-60 Ma hydration of lower lithosphere under cool

449 temperatures (Smith and Griffin, 2005), and hydration-enabled erosion of $>10 \mathrm{~km}$ of basal North

450 American lithosphere (Li et al., 2008), implies that Farallon slab was in contact with the base of

451 the continent. Under these conditions the Farallon crust probably would be too cool (English et

452 al., 2003; Currie and Beaumont, 2011; Menea et al., 2012) to overcome the activation barrier

453 required for eclogite transformation (of $\sim 600-800^{\circ} \mathrm{C}$, van Hunen et al., 2004). Uplift above sea

454 level and creation of km-scale relief in the SW Colorado Plateau at 80-70 Ma (Flowers et al.,

455 2008; Flowers and Farley, 2012) corresponds to the time when the Shatsky conjugate passed

456 beneath this region (Fig. 4, Liu et al., 2008), consistent with the idea that the Shatsky conjugate

457 passed through this region with a basaltic crust. It may be possible that some of the oceanic crust

458 was lost beneath the Colorado Plateau, as suggested by Usui et al. (2003) based on their

459 interpretation of xenoliths, or near the Cheyenne Belt, consistent with the region's anomalously 
460 dense crust (Crosswhite and Humphreys, 2002). It remains unknown, however, how much of the 461 Farallon crust may have been transferred to the base of the North America interior during transit. 462 In contrast to SW Colorado Plateau uplift, sediments deposited into large basins in NW 463 Colorado and southern Wyoming record major subsidence at 85-70 Ma (Cook and Bally, 1975; 464 Roberts and Kirschbaum, 1995; Liu et al., 2011; Chapin, 2012). The Shatsky conjugate is 465 thought to have arrived to this area at $\sim 75-70 \mathrm{Ma}$ (Fig. 4), i.e., towards the end of this anomalous 466 subsidence event (Liu et al. Supplement, 2010, and Fig. S5). We infer that the subsidence 467 indicates eclogitization of the Farallon ocean crust, and then Shatsky-conjugate crust, as they 468 reached this location. Indeed, if the Shatsky conjugate passed by with basaltic crust, we would 469 expect an uplift event similar in magnitude to that experienced by the SW Colorado Plateau.

470 Thermal evolution models of flat-subducting ocean lithosphere predict that the crust would have 471 attained temperatures of about $500-800^{\circ} \mathrm{C}$ (depending on conditions) in this vicinity (English et 472 al., 2003; Currie and Beaumont, 2011; Menea et al., 2012).

473 A waning of sediment deposition in the NE Colorado and southern Wyoming basins 474 indicates the region began to emerge at $\sim 75 \mathrm{Ma}$ in NW Colorado and $\sim 70 \mathrm{Ma}$ in south-central 475 Wyoming (Roberts and Kirschbaum, 1995). This suggests a removal of the load that drove 476 downwarping. If eclogitic ocean crust was the load, then the rebound may well represent the 477 eclogite loss, presumably to the Earth's interior.

478 The Colorado Mineral Belt initiated at $\sim 75 \mathrm{Ma}$ (Fig. S6, Jones et al., 2011; Chapin, 2012 479 and references therein). These plutons are largely crustal melts, although heating probably 480 necessitated mantle-derived magma. Accounting for asthenospheric access has been a problem 481 because volcanism across most of the western U.S. had ended, which usually is attributed to flat482 slab subduction. Jones et al. (2011) suggest small-scale mantle flow within a narrow mantle 
483 wedge above a shallowly dipping slab, whereas Chapin (2012) suggests a tearing of the flat

484 Farallon slab below the Colorado Mineral Belt. In our preferred reconstruction (Figs. 4 and S6),

485 the SW margin of the Shatsky conjugate lies directly below the Colorado Mineral Belt at 75 Ma.

486 We infer that an eclogitized Shatsky-conjugate ocean crust escaped in some fashion through a

487 tear in the Farallon slab beneath the Shatsky conjugate, starting at $\sim 75$ Ma. Crustal mobility may

488 have been a product of low viscosity induced by the presence of eclogetic quartz, crustal fabric,

489 shear stress, the presence of water or recrystallization during transformation.

\section{$491 \quad$ 5. Summary and Discussion}

A consideration of seismic tomography, isostasy, xenoliths, and plate tectonic history

494 provides a case for the under accretion of the Shatsky conjugate beneath Wyoming at 265 Ma.

495 Xenoliths appear to record the local erosion of $\sim 30-50 \mathrm{~km}$ of Archean lithosphere from basal

496 North America, and the emplacement of young, depleted mantle beneath the Wyoming craton.

497 Isostatic considerations of the Wyoming area indicate a current mantle buoyancy that is neutral

498 to positive relative to times before $125 \mathrm{Ma}$, but that there was a phase of negative buoyancy

499 beneath the region north of the current Colorado Mineral Belt that ended 75-70 Ma. Seismic

500 tomography images high-velocity mantle to depths of $\sim 230-310 \mathrm{~km}$, deepest beneath NE

501 Wyoming. The buoyancy of this high-velocity mantle seems to require that it is depleted of

502 basaltic component. The creation of a large, cool and depleted volume of mantle lithosphere

503 beneath a craton within the continental interior would normally be difficult to explain. However,

504 in an unusual tectonic event, a large ocean plateau subducted beneath North America when and

505 where it is needed. To deposit the ocean plateau where imaged, it must stop subducting at $~ 65$ 
Ma. Fig. 5 illustrates the basic elements of this history. Cross sections of the inferred initial

507 Farallon lithosphere that contains the Shatsky conjugate, and that of the initial and final North

508 American lithosphere, are discussed in the Supplement and Fig. S4.

$509 \quad$ Our model has the Shatsky conjugate ocean plateau subducting with its crust but under-

510 accreting Wyoming without its crust. If we assume that this model is correct, we look to the

511 history of vertical motion along this plateau's path to understand where and how the ocean crust

512 was separated from the depleted-mantle portion of the plateau. These motions suggests the ocean

513 crust transformed to eclogite beneath NW Colorado and was subsequently lost starting $\sim 75$ Ma.

514 Because most of this crust is missing, a loss to the deeper mantle seems likely. The coincident

515 initiation of the Colorado Mineral Belt indicates a probable tear in the Farallon (Chapin, 2012),

516 which could provide a pathway for this loss.

517 Debate continues on origin of cratons. In this paper we describe a young slab-stacking

518 event in which an Archean-like piece of ocean lithosphere was made by a hotspot at a spreading

519 center (creating a relatively highly depleted mantle lithosphere) and subsequently subducted

520 beneath southern California. As in the Archean slab-stacking hypothesis, the oceanic crust has

521 been lost. In our case, however, the geologic record of anomalous vertical motions in Colorado

522 and Wyoming and the initiation of the Colorado Mineral Belt volcanic trend can be used to

523 suggest that this loss may have occurred through a tear in the subducted Farallon slab.

524 The basement-cored uplifts characteristic of Laramide orogeny began $\sim 75$ Ma i.e., well

525 after the subduction of the Shatsky conjugate and during our proposed Shatsky crustal loss event.

526 It was at $\sim 75 \mathrm{Ma}$ that compressive stress in the Rocky Mountain region switched from east-

527 oriented to NE-oriented (Bird, 2002). In the following 10 m.y., during the time when we infer

528 the Shatsky conjugate mantle lithosphere was being transported to beneath Wyoming, the 
529 Wyoming thrust system developed (with the other Laramide thrusts initiating later) (Bird, 2002).

530 It is interesting to note that the Shatsky conjugate appears to have been transferred from the

531 Farallon lithosphere to the North America when the plateau encountered the Archean craton.

532

533 Acknowledgments

534

535 We thank Rick Carlson, Craig Jones, Roberta Rudnick, David Snyder, Stephan Sobolev and Jens

536 Tympel for useful and enjoyable conversations, Hersh Gilbert and Cin-Ty Lee for helpful

537 reviews, and Peter Shearer for handling the editorial responsibilities. We acknowledge support

538 from the CIDER program (EAR-1135452) and from NSF grants EAR-1052899 and EAR-

5390952194 to $\mathrm{EH}$.

540

$541 \quad$ References

542

543 Arndt, N.T., Coltice, N., Helmstaedt, H., and Gregoire, M. (2009), Origin of Archean

544 subcontinental lithospheric mantle: Some petrological constraints. Lithos, 109(1), 61-71.

545 Artemieva, I.M. (2009), The continental lithosphere: reconciling thermal, seismic, and petrologic

546 data. Lithos, 109, 23-46.

547 Ashchepkov, I.V., Downes, H., Mitchell, R., Vladykin, N.V., Coopersmith, H., and Palessky,

548 S.V. (2013), Wyoming Craton Mantle Lithosphere: Reconstructions Based on Xenocrysts

549 from Sloan and Kelsey Lake Kimberlites, in D.G. Pearson et al. (eds.), Proceedings of 10th

550 International Kimberlite Conference, Volume 1, Special Issue of the Journal of the

$551 \quad$ Geological Society of India. 
552 Bailey, I. W., Miller, M. S., Liu, K., and Levander, A. (2012), VS and density structure beneath

553 the Colorado Plateau constrained by gravity anomalies and joint inversions of receiver

554 function and phase velocity data, J. Geophys. Res., 117.

555 Becker, T.W., and Boschi, L. (2002), A comparison of tomographic and geodynamic mantle

556 models, Geochemistry, Geophysics, Geosystems, 3, $2001 \mathrm{GC} 9000168$.

557 Becker, T.W., Faccenna, C., Humphreys, E.D., Lowry, A.R., and Miller, M.S. (2013), Static and 558 dynamic support of western United States topography, Earth Planet. Sci. Lett., 402, 234-246.

559 Bird, P. (1998), Kinematic history of the Laramide orogeny in latitudes $35^{\circ}-49^{\circ} \mathrm{N}$, western

$560 \quad$ United States, Tectonics, 17, 780-801.

561 Bird, P. (2002), Stress direction history of the western United States and Mexico since 85 Ma, 562 Tectonics, 21(3), 5-1.

563 Blackburn, T.J., Bowring, S.A., Perron, J.T., Mahan, K., Dudas, F.O., and Barnhart, K.R. (2012),

564 An exhumation history of continents over billion-year time scales, Science, 335, 73-76.

565 Blackwell, D.D., J.L. Steele, and L.C. Carter (1991), Heat flow patterns of the North American

566 continent: A discussion of the DENAG geothermal map of North America, in Slemmons,

567 D.B., Engdahl, E.R., Zoback, M.D., and Blackwell, D.D., eds., Neotectonics of North

568 America: Boulder, Colorado, Geol. Soc. Am., Decade Map Volume 1.

569 Blakey, R.C., and Ranney, W. (2008), Ancient landscapes of the Colorado Plateau, Grand

$570 \quad$ Canyon Assn., Grand Canyon, AZ, p. 156.

571 Brocher, T.M. (2005), Empirical relations between elastic wavespeeds and density in the Earth's

$572 \quad$ crust, Bull. Seism. Soc. Am. 95, 2081-2092.

573 Cammarano, F., Goes, S., Vacher, P., and Giardini, D. (2003), Inferring upper-mantle

574 temperatures from seismic velocities. Physics Earth Planet. Int., 138, 197-222. 
575 Cammarano, F., Romanowicz, B., Stixrude, L., Lithgow-Bertelloni, C., and Xu, W. (2009),

576 Inferring the thermochemical structure of the upper mantle from seismic data. Geophys. $J$. 577 Int., 179(2), 1169-1185.

578 Carlson, R.W., Irving, A.J., and Hearn Jr, B.C. (1999), Chemical and isotopic systematics of 579 peridotite xenoliths from the Williams kimberlite, Montana: clues to processes of lithosphere 580 formation, modification and destruction, In Proceedings of the VIIth International Kimberlite $581 \quad$ Conference (Vol. 1, pp. 90-98).

582 Carlson, R.W., Irving, A.J., Schulze, D.J., and Hearn Jr, B.C. (2004), Timing of Precambrian 583 melt depletion and Phanerozoic refertilization events in the lithospheric mantle of the $584 \quad$ Wyoming Craton and adjacent Central Plains Orogen, Lithos, 77, 453-472.

585 Chamberlain, K.R., Frost, C.D., and Frost, B.R. (2003), Early Archean to Mesoproterozoic 586 evolution of the Wyoming Province: Archean origins to modern lithospheric architecture. 587 Canadian J. Earth Sci., 40, 1357-1374.

588 Chapin, C.E. (2012), Origin of the Colorado mineral belt, Geosphere, 8, 28-43.

589 Chapman, A.D., Kidder, S., Saleeby, J.B., Ducea M.N. (2010), Role of extrusion of the Rand and 590 Sierra de Salinas schists in Late Cretaceous extension and rotation of the southern Sierra $591 \quad$ Nevada and vicinity, Tectonics, doi:10.1029/2009TC002597.

592 Coney, P.J., and Reynolds, S.J. (1977), Cordilleran benioff zones. Nature, 270, 403-406.

593 Cook, T.D., and A.W. Bally (1975), Stratigraphic Atlas of North and Central America, 272 pp., 594 Princeton Univ. Press, Princeton, N.J.

595 Cooper, C.M., Lenardic, A., and Moresi, L. (2004), The thermal structure of stable continental 596 lithosphere within a dynamic mantle, Earth Planet. Sci. Lett., 222, 807-817. 
Crosswhite, J.A., and Humphreys, E.D. (2003), Imaging the mountainless root of the $1.8 \mathrm{Ga}$

598 Cheyenne belt suture and clues to its tectonic stability, Geology, 31, 669-672.

599 Currie, C.A., and Beaumont, C. (2011), Are diamond-bearing Cretaceous kimberlites related to 600 low-angle subduction beneath western North America?, Earth Planet. Sci. Lett., 303, 59-70.

601 DeCelles, P.G. (2004), Late Jurassic to Eocene evolution of the Cordilleran thrust belt and

602 foreland basin system, western U.S.A., Am. J. Sci., 304, 105-168.

603 Dickinson, W.R., Klute, M.A., Hayes, M.J., Janecke, S.U., Lundin, E.R., McKittrick, M.A., and

604 Olivares, M.D. (1988), Paleogeographic and paleotectonic setting of Laramide sedimentary

605 basins in the central Rocky Mountain region, Geol. Soc. Am. Bull., 100, 1023-1039.

606 Eggler, D.H., J.K. Meen, F. Welt, F.O. Dudas, K.P. Furlong, M.E. McCallum and R.W. Carlson

607 (1988), Tectonomagmatism of the Wyoming Province, in J. Drexler and E.E. Larson, eds.,

608 Colorado Volcanism, Colorado School of Mines Quarterly, Boulder, 25-40.

609 English, J.M, S.T. Johnson, K Wang, 2003, Thermal modeling of the Laramide orogeny: testing

610 the flat-slab subduction hypothesis, Earth Planet. Sci. Lett., 214, 619-632.

611 Erslev, E.A., and N.V. Koenig (2009), Three-dimensional kinematics of Laramide, basement-

612 involved Rocky Mountain deformation, USA: Insights from minor faults and GIS-enhanced

613 structure maps, Geol. Soc. Am. Bull. Memoir 204, 125-150.

614 Fan, M., and Carrapa, B. (2014), Late Cretaceous-early Eocene Laramide uplift, exhumation,

615 and basin subsidence in Wyoming: Crustal responses to flat slab subduction, Tectonics, 3 , $616 \quad 509-529$.

617 Flowers, R. M., and Farley, K.A. (2012), Apatite 4He/3He and (U-Th)/He evidence for an 618 ancient Grand Canyon, Science, 338, 1616-1619.

619 Flowers, R. M., Wernicke, B. P., and Farley, K. A. (2008), Unroofing, incision, and uplift history 
of the southwestern Colorado Plateau from apatite (U-Th)/He thermochronometry, Geol. Soc.

$621 \quad$ Am. Bull., 120, 571-587.

622 Gilbert, H. (2012), Crustal structure and signatures of recent tectonism as influenced by ancient 623 terranes in the western United States, Geosphere, 8(1), 141-157.

624 Gilbert, H.J., Sheehan, A.F., Dueker, K.G., and Molnar, P. (2004), Receiver functions in the 625 western United States, with implications for upper mantle structure and dynamics, $J$. 626 Geophys. Res., 108.

627 Grove, M., Bebout, G.E., Jacobson, C.E., Barth, A.P., Kimbrough, D.L., King, R.L., Zou, H., 628 Lovera, O.M., Mahoney, B.J., and Gehrels, G.E. (2008), The Catalina Schist: evidence for 629 middle Cretaceous subduction erosion of southwestern North America, Geol. Soc. Am. $630 \quad$ Special Papers, 436, 335-361.

631 Grove, M., Jacobson, C.E., Barth, A.P., and Vucic, A. (2003), Temporal and spatial trends of 632 Late Cretaceous-early Tertiary underplating of Pelona and related schist beneath southern 633 California and southwestern Arizona, Sp. Pap. 374, Geol. Soc. Am., 381-406.

634 Hasterok, D., and Chapman, D. S. (2007), Continental thermal isostasy: 2. Application to North 635 America, J. Geophys. Res, 112.

636 Hager, B.H., and O'Connell, R.J. (1981), A simple global model of plate dynamics and mantle 637 convection, J. Geophys. Res., 86, 4843-4867.

638 Haq, B.U., Hardenbol, J., and Vail, P.R. (1988), Mesozoic and Cenozoic chronostratigraphy and 639 cycles of sea-level change, Soc. Econ. Paleo. Min. Special Pub. 42.

640 Hearn Jr., B.C. (2004), The Homestead kimberlite, central Montana, USA: mineralogy, $641 \quad$ xenocrysts, and upper-mantle xenoliths, Lithos 77, 473-491. 
642 Hopper, E., Ford, H. A., Fischer, K. M., Lekić, V., and Fouch, M. J. (2014), The lithosphere-

643 asthenosphere boundary and the tectonic and magmatic history of the northwestern United 644 States. Earth Planet. Sci. Lett., 402, 69-81.

645 Jacobson, C.E., Grove, M., Pedrick, J.N., Barth, A.P., Marsaglia, K.M., Gehrels, G.E., and 646 Nourse, J.A. (2011), Late Cretaceous-early Cenozoic tectonic evolution of the southern 647 California margin inferred from provenance of trench and forearc sediments, Geol. Soc. Am. $648 \quad$ Bull., 123, 485-506.

649 Jones, C.H., Farmer, G.L., Sageman, B., and Zhong, S. (2011), Hydrodynamic mechanism for 650 the Laramide orogeny. Geosphere, 7, 183-201.

651 Jones, C.H., Mahan, K.H., Butcher, L.A., Levandowski, W.B., and Farmer, G.L. (2015), 652 Continental uplift through crustal hydration, Geology, 43(4), 355-358.

653 Jordan, T.H. (1978), Composition and development of the continental tectosphere. Nature, $654 \quad 274(5671), 544-548$.

655 Jordan, T.H. (1988), Structure and formation of the continental tectosphere. J. Petrology, 1, 1165637.

657 Karlstrom, K., Coblentz, D., Dueker, K., Ouimet, W., Kirby, E., Van Wijk, J., Umhoefer, P, and 658 Donahue, M. (2012), Mantle-driven dynamic uplift of the Rocky Mountains and Colorado 659 Plateau and its surface response: Toward a unified hypothesis, Lithosphere, 4(1), 3-22.

660 Korenaga, J., and Sager, W.W. (2012), Seismic tomography of Shatsky Rise by adaptive 661 importance sampling, J. Geophys. Res., 117.

662 Lee, C.-T.A., Luffi, P., and Chin, E.J. (2011), Building and destroying continental mantle. 663 Annual Review of Earth and Planetary Sciences, 39, 59-90. 
664 Lekić, V., and K.M. Fischer (2013), Contrasting lithospheric signatures across the western

665 United States revealed by Sp receiver functions, Earth Planet. Sci. Lett., 402, 90-98.

666 Levander, A., and M.S. Miller (2012), Evolutionary aspects of lithosphere discontinuity structure 667 in the western U.S., Geochem. Geophys. Geosyst., 13, Q0AK07.

668 Levander, A., B. Schmandt, M. Miller, K. Liu, K. Karlstrom, R. Crow, C.-T. Lee, E. Humphreys

669 (2011), Continuing Colorado plateau uplift by delamination-style convective lithospheric 670 downwelling. Nature, 472, 461-465.

671 Levandowski, W., Jones, C.H., Shen, W., Ritzwoller, M.H., and Schulte-Pelkum, V. (2014),

672 Origins of topography in the western US: Mapping crustal and upper mantle density

673 variations using a uniform seismic velocity model, J.Geophys. Res., 119, 2375-2396.

674 Li, Z.-X.A., C.-T.A. Lee, A.H. Peslier, A. Lenardic, and S.J. Mackwell (2008), Water contents in

675 mantle xenoliths from the Colorado Plateau and vicinity: Implications for the mantle

676 rheology and hydration-induced thinning of continental lithosphere, J. Geophys. Res., 113, 677 B09210, doi:10.1029/2007JB005540.

678 Lin, F.-C., Tsai, V.C., and Schmandt, B. (2014), 3-D crustal structure of the western United 679 States: application of Rayleigh-wave ellipticity extracted from noise cross-correlations, 680 Geophys. J. Int., 198, 656-670.

681 Liu, L. and M. Gurnis, M. Seton J. Saleeby, R.D. Müller, and J. Jackson (2010), The role of 682 oceanic plateau subduction in the Laramide orogeny, Nature Geoscience, 3, 353-357.

683 Liu, L., and Nummedal, D. (2004), Late Cretaceous subsidence in Wyoming: Quantifying the 684 dynamic component, Geology, 32, 397-400. 
685 Liu, S., Nummedal, D., and Liu, L. (2011), Migration of Dynamic subsidence across the Late

686 Cretaceous United States Western Interior Basin in response to Farallon plate subduction, 687 Geology, 39, 555-558.

688 Liu, L.J., Spasojevic, S., and Gurnis, M. (2008), Reconstructing Farallon plate subduction

689 beneath North America back to the Late Cretaceous, Science, 322, 934-938.

690 Liu, L., and Stegman, D.R. (2011), Segmentation of the Farallon slab, Earth Planet. Sci. Lett., $691 \quad 311(1), 1-10$.

692 Livaccari, R.F., Burke, K., and Şengör, A.M.C. (1981), Was the Laramide Orogeny related to 693 subduction of an oceanic plateau?. Nature, 289, 276-278

694 Lowry, A.R., and Pérez-Gussinyé, M. (2011), The role of crustal quartz in controlling

695 Cordilleran deformation, Nature, 471, 353-357.

696 Luffi, P., Saleeby, J.B., Lee, C.-T.A., and Ducea, M.N. (2009), Lithospheric mantle duplex

697 beneath the central Mojave Desert revealed by xenoliths from Dish Hill, California, $J$.

698 Geophys. Res., 114, B03202.

699 McMillan, M.E., Heller, P.L., and Wing, S.L. (2006), History and causes of post-Laramide relief

700 in the Rocky Mountain orogenic plateau, Geol. Soc. Am. Bull., 118, 393-405.

701 Manea, V.C., Pérez-Gussinyé, M., and Manea, M. (2012), Chilean flat slab subduction controlled 702 by overriding plate thickness and trench rollback, Geology, 40(1), 35-38.

703 Mitrovica, J.X., Beaumont, C., and Jarvis, G.T. (1989), Tilting of continental interiors by the 704 dynamical effects of subduction, Tectonics, 8, 1079-1094.

705 Molenaar, C.M., and Rice, D.D. (1988), Cretaceous rocks of the Western Interior basin, in Sloss,

706 L.L., ed., Sedimentary cover- North America Craton: U.S., Boulder, CO, Geol. Soc. Am., 707 Geology of North America, v. D-2, 77-82. 
Nakanishi, M., Sager, W.W., and Klaus, A. (1999), Magnetic lineations within Shatsky Rise,

709 northwest Pacific Ocean: Implications for hot spot-triple junction interaction and oceanic

710 plateau formation J. Geophy. Res., 104, B4, 7539-7556.

711 Patino-Douce, A, Humphreys, E.D, Johnston, A.D., 1990, Anatexis and metamorphism in 712 tectonically thickened continental crust exemplified by the Sevier Hinterland, western North 713 America, Earth Planet. Sci. Lett., 97, 290-315.

714 Peterson, J.A. (1988), Phanerozoic stratigraphy of the northern Rocky Mountains, in Sloss, L.L., 715 ed., Sedimentary cover- North America Craton: U.S., Boulder, CO, Geol. Soc. Am., 716 Geology of North America, v. D-2, 83-107.

717 Reed, J.C., Wheeler, J.O., and Tucholke, B.E., compliers (2005), Geologic Map of North 718 America, Decade of North America Geology, Continental scale map 001, Boulder, 719 Geological Society of America, scale 1:5,000,000.

720 Roberts, L.N.R., and Kirschbaum, M.A. (1995), Paleogeography of the Late Cretaceous of the 721 Western Interior of middle North America - Coal distribution and sediment accumulation, $722 \quad$ U.S. Geological Survey Professional Paper 1561, 155 p.

723 Sager, W.W., Zhang, J., Korenaga, J., Sano, T., Koppers, A.A., Widdowson, M., and Mahoney, 724 J. J. (2013), An immense shield volcano within the Shatsky Rise oceanic plateau, northwest $725 \quad$ Pacific Ocean. Nature Geoscience, 6(11), 976-981

726 Saleeby, J. (2003), Segmentation of the Laramide slab-Evidence from the southern Sierra 727 Nevada region, Geol. Soc. Am. Bull., 115, 655-668.

728 Schmandt, B., Dueker, K., Humphreys, E.D., Hansen, S. (2012), Hot mantle upwelling across the 729660 beneath Yellowstone, Earth Planet. Sci. Lett., 331-2, 224-236.

730 Schmandt, B., Humphreys, E.D. (2010), Complex subduction and small-scale convection 
revealed by body-wave tomography of the western United States upper mantle, Earth Planet.

732 Sci. Lett., 297, 435-445.

733 Schultz, D.J., Coppersmith, H.G., Harte, B., and Pizzolato, L-A. (2008), Mineral inclusions in

734 diamonds from the Kelsey Lake Mine, Colorado, USA: Depleted Archean mantle beneath the 735 Proterozoic Yavapai province, Geochimica et Cosmochimica Acta 72, 1685-1695.

736 Schutt, D.L., and Lesher, C.E. (2006), Effects of melt depletion on the density and seismic 737 velocity of garnet and spinel lherzolite., J. Geophys. Res., 111.

738 Scott, R.W., Oboh-Ikuenobe, F.E., Benson Jr., D.G., and Holbrook, J.M. (2009), Numerical age 739 calibration of the Albian/Cenomanian boundary, Stratigraphy, 6, 17.

740 Shen, W., Ritzwoller, M.H., and Schulte-Pelkum, V. (2013), A 3-D model of the crust and 741 uppermost mantle beneath the Central and Western US by joint inversion of receiver 742 functions and surface wave dispersion. J. Geophys. Res., 118, 262-276. Model download at 743 ciei.colorado.edu/Models (07/28/2015).

744 Sloss, L.L. (1988), Tectonic evolution of the craton in the Phanerozoic time (p. 45), in Sloss,

745 L.L. ed., Sedimentary Cover- North American Craton: U.S.: Conterminous U.S.: Boulder, 746 CO, Geological Society of America, Geology of North America, v. D-2, 25-51.

747 Smith, D. (2010), Antigorite peridotite, metaserpentinite, and other inclusions within diatremes 748 on the Colorado Plateau, SW USA: Implications for the mantle wedge during low-angle 749 subduction, J. Petrology, 51, 1355-1379.

750 Smith, D., and Griffin, W.L. (2005), Garnetite xenoliths and mantle-water interactions below the 751 Colorado Plateau, southwestern United States, J. Petrology, 46(9), 1901-1924. 
752 Snyder, D. B., Hillier, M. J., Kjarsgaard, B. A., de Kemp, E. A., and Craven, J. A., 2014,

753 Lithospheric architecture of the Slave craton, northwest Canada, as determined from an

754 interdisciplinary 3-D model, Geochem. Geophys. Geosyst, 15, 1895-1910.

755 Spasojevic, S., Liu, L., and Gurnis, M. (2009), Adjoint models of mantle convection with

756 seismic, plate motion, and stratigraphic constraints: North America since the Late

757 Cretaceous, Geochem. Geophys. Geosyst., 10, Q05W02, doi:10.1029/2008GC002345.

758 Spencer, J.E. (1996), Uplift of the Colorado Plateau due to lithosphere attenuation during

759 Laramide low-angle subduction, J. Geophys. Res., 101, 13,595-13,609.

760 Stixrude, L., and Lithgow-Bertelloni, C. (2011), Thermodynamics of mantle minerals-II. Phase

761 equilibria, Geophy. J. Int., 184, 1180-1213.

762 Usui, T., Nakamura, E., Kobayashi, K., Maruyama, S., and Helmstaedt, H. (2003), Fate of the

763 subducted Farallon plate inferred from eclogite xenoliths in the Colorado

764 Plateau, Geology, 31, 589-592.

765 van Hunen, J., van den Berg, A.P., and Vlaar, N.J. (2004), Various mechanisms to induce

766 present-day shallow flat subduction and implications for the younger Earth: a numerical

767 parameter study, Physics Earth Planet. Interiors, 146, 179-194.

768 Whitmeyer, S.J., and Karlstrom, K.E. (2007), Tectonic model for the Proterozoic growth of

769 North America, Geosphere, 3, 220-259.

770 Yeck, W.L., Sheehan, A.F., Anderson, M.L., Erslev, E.A., Miller, K.C., and Siddoway, C. S.

771 (2014), Structure of the Bighorn Mountain region, Wyoming, from teleseismic receiver

772 function analysis: Implications for the kinematics of Laramide shortening, J. Geophys. Res.,

$773 \quad 119,7028-7042$.

774

775 Figure Captions 
777 Fig. 1. Upper mantle seismic structure. (a) Depth slices. Top row shows Sv seismic perturbations

778 from the Rayleigh-wave tomography of Shen et al. (2013), interpolated onto the model nodes of

779 the teleseismic P-wave tomography model of Schmandt and Humphreys, 2010a (also shown is

780 the interpolated result at $75 \mathrm{~km}$ depth). The bottom two rows show the $\mathrm{P}$-wave model at node

781 depths in the upper mantle to depths of $400 \mathrm{~km}$. Note that the two models are shown the same

782 depths above $200 \mathrm{~km}$.

783 (b) Cross sections. These three cross sections cross in NE Wyoming near the deepest part of the

784 high-velocity upper-mantle structure. The dashed line at 120-km depth separates the S-wave

785 model from the deeper P-wave model. The narrow panels show the S-wave model to depths of

$786160 \mathrm{~km}$. The approximate Moho depth is shown. Moho depth variations show up as lateral

787 velocity variations near this depth.

788 We argue that the prominent high-velocity structure is a deep volume of relatively cool basalt-

789 depleted mantle within the NE part of the Shatsky conjugate, created beneath the conjugate

790 Tamu volcano.

791

792 Fig. 2. Xenolith sampling of the deep lithosphere.

793 (a) Map showing the sites of the two kimberlites that sampled to depths of $\sim 200 \mathrm{~km}$. Dashed

794 lines show the approximate boundaries of cratons, with the Wyoming craton nearest the center.

795 The Colorado (CO) site erupted in the Devonian just south of the Proterozoic-Archean suture.

796 The Montana (MT) site erupted in Archean crust during the Eocene, but lies very near the

797 Proterozoic Great Falls Tectonic Zone (GFTZ). Background image is the depth slice at $160 \mathrm{~km}$

798 from the P-wave model shown in Fig. 1. 
(b) Temperature-depth plot of xenoliths from the two sites shown in (a). Figure after Eggler et al.

800 (1988). The Devonian Colorado xenoliths (green) define a cool geotherm to $\sim 200 \mathrm{~km} \mathrm{depth}$, and

801 the deeper population sampled depleted Archean mantle. The Eocene Montana xenoliths

802 (orange) have two distinct populations. A depleted Archean "low temperature" population (blue

803 stripes) lies on a cool geotherm (between $40-45 \mathrm{~mW} / \mathrm{m}^{2}$ ), typical of cratons around the world

804 (Artemiva, 2009) and samples to depths of $\sim 140 \mathrm{~km}$. The extension of this geotherm to mantle

805 solidus temperatures (pink, from Artemiva, 2009) defines a pre-Laramide craton of 170-230 km

806 thickness. A depleted "high temperature" population (red stripes) lies on a warm geotherm (> 45

$807 \mathrm{~mW} / \mathrm{m}^{2}$ ) and samples depths of $\sim 160-200 \mathrm{~km}$. Unlike the other xenoliths plotted on this figure,

808 these xenoliths have an age younger than the Paleozoic. Apparently the cool, $\sim 200-\mathrm{km}$ thick

809 craton was truncated at 140-160 km depth, with the deeper mantle being replaced by relatively

810 young and depleted mantle that was created at relatively high temperature.

812 Fig. 3. Elevation contributions since $125 \mathrm{Ma}$ (i.e., since the early Sevier orogeny). All significant

813 contributions have been included except the changes in uppermost mantle density and lower

814 crustal hydration, and hence the unpredicted elevation is an estimate for the changes in upper

815 mantle buoyancy plus lower crustal buoyancy due to hydration. All units are in km. All fields

816 have been smoothed with a low-pass Gaussian filter that reduces signal amplitude by $50 \%$ at a

817 wavelength of $150 \mathrm{~km}$. See section 3.3 for details.

818 (a) Actual elevation. The "Y" indicates the location of Yellowstone.

819 (b) Dynamic topography created by density structure deeper than $200 \mathrm{~km}$. The result is an

820 inconsequential 50-70 $\mathrm{m}$ of subsidence.

821 (c) Initial elevation, taken from the estimated elevation at $125 \mathrm{Ma}$. 
822 (d) Elevation created by post-125 Ma sediment.

823 (e) Elevation in (d) plus elevation effects (reduction) created by erosion since $125 \mathrm{Ma}$.

824 (f) Elevation created by crustal thickening 40-80 Ma (mostly of Laramide origin).

825 (g) Elevation created by post-Laramide crustal heating (from Levandowski et al., 2014).

826 (h) Predicted elevation.

827 (i) Elevation anomaly (actual elevation - predicted elevation). The circles show the elevation

828 anomaly calculated by Spencer (1996), and the squares show the uplift predicted by Jones et al.

829 (2015) resulting from lower crustal hydration. Plausibly, much of the Wyoming elevation

830 anomaly in (i) is caused by lower crustal hydration, which would suggest that Wyoming upper

831 mantle currently is as buoyant as it was prior to the Sevier orogeny.

833 Fig. 4. Estimated shape and path of the Shatsky conjugate beneath North America. Map is

834 modified after Liu et al. (2010). The base map is a palinspastic reconstruction for $\sim 65 \mathrm{Ma}$; black

835 dots represent outcrops of the Pelona-type schist. See the section 4 and the Supplement for

836 additional details. The circled grey numbers show the time (in m.y.) when the main volcanic

837 construction (conjugate Tamu massif) was at the indicated location, from Liu et al. (2010), with

838 the grey line indicating their path. We modify this path (to the line with colored age numbers) so

839 as to $(i)$ match the geologic record that we associate with the passage of the plateau - especially

840 its passage beneath the greatly disrupted southern California crust (indicated with the two short

841 black lines) - and (ii) ending with the Shatsky conjugate being co-located with the major high-

842 velocity upper-mantle seismic structure and with the conjugate Tamu massif located where we

843 image the major deep high-velocity structure shown in the inset. For each time we show the

844 contours for crust of 17 and $27 \mathrm{~km}$ inferred thickness, and at $65 \mathrm{Ma}$ we also include the contour 
845 for $10 \mathrm{~km}$ inferred thickness. The inferred location of the Shatsky conjugate at the time (75 Ma)

846 it was adjacent to the Colorado Mineral Belt (CMB) is shown with a heavy outline. We have the

847 Shatsky conjugate stopping beneath North America at $\sim 65 \mathrm{Ma}$. The inset shows the tomography

848 image at $195 \mathrm{~km}$ depth, from Fig. 1, and the outline of inferred Shatsky conjugate at $65 \mathrm{Ma}$.

850 Fig. 5. Inferred history of Shatsky conjugate ocean plateau subduction beneath North America.

851 (a) The inferred path of the ocean plateau beneath North America. Ages (in Ma) are located at

852 the Tamu massif. See Fig. 4 for additional description. (b) Cross section along the trajectory of

853 the ocean plateau at $75 \mathrm{Ma}$, viewed looking toward the SE. Farallon ocean lithosphere is shown

854 in shades of green. Thermal lithosphere, represented with a thickness of $100 \mathrm{~km}$, is shown in

855 light green. Depleted mantle is represented with dark green, where its thickness simply

856 represents the amount of basaltic melt that has been removed during plateau construction. The

857 "T" indicates the Tamu part of the plateau. Ocean crust is shown in black and red, where red

858 indicates the presence of eclogite. North America lithosphere is shown in shades of brown, with

859 the crust shown in light brown. Dashed line shows eventual location of the North American base,

860 which is eroded to this depth during the Sevier/Laramide orogeny. CP is Colorado Plateau. At 75

861 Ma the Colorado Mineral belt (CMB) and the Laramide orogeny both initiate. We suggest that

862 the eclogized crust of the ocean plateau sinks into the Earth's interior through a tear in the

863 Farallon slab located beneath the $\mathrm{CMB}$, contributing to regional uplift and initiating CMB

864 magmatism. (c) Cross section at $65 \mathrm{Ma}$. The Shatsky conjugate has lost most of its crust, and it

865 accretes to North America beneath Wyoming and the Colorado Plateau near this time. 
Fig. 1a

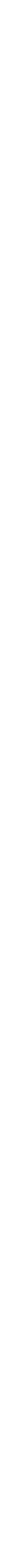




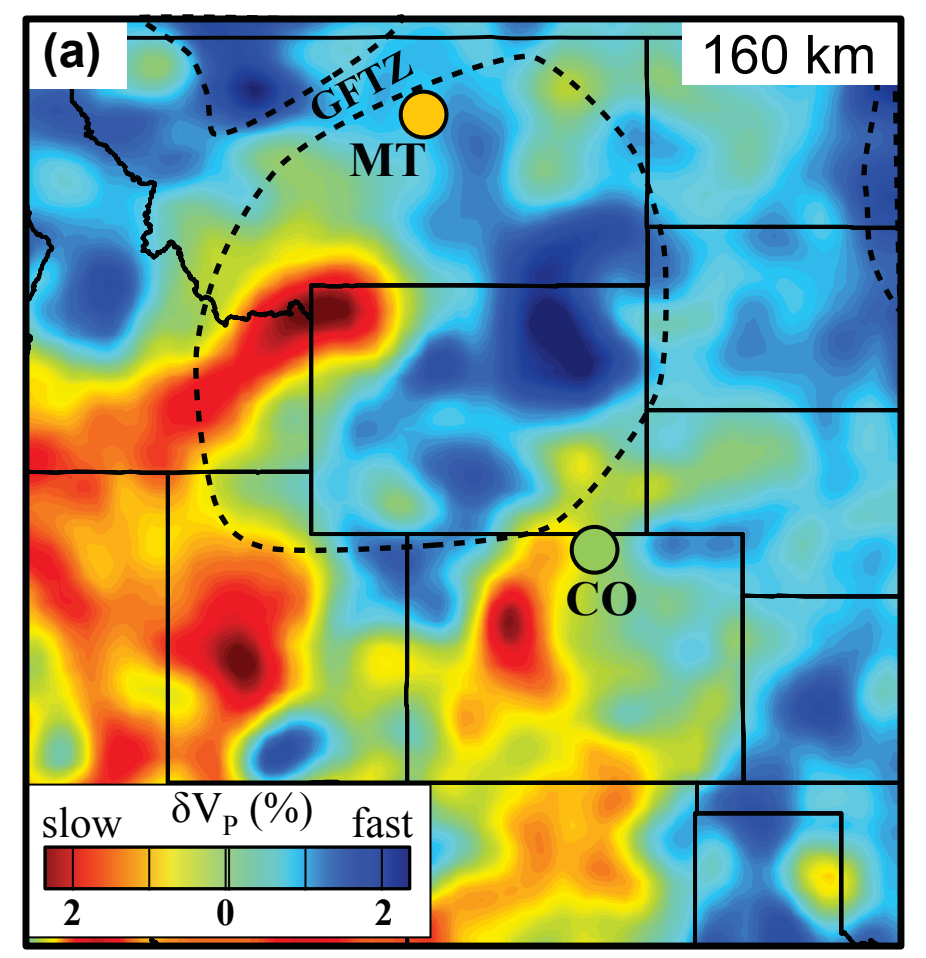

Fig. 2

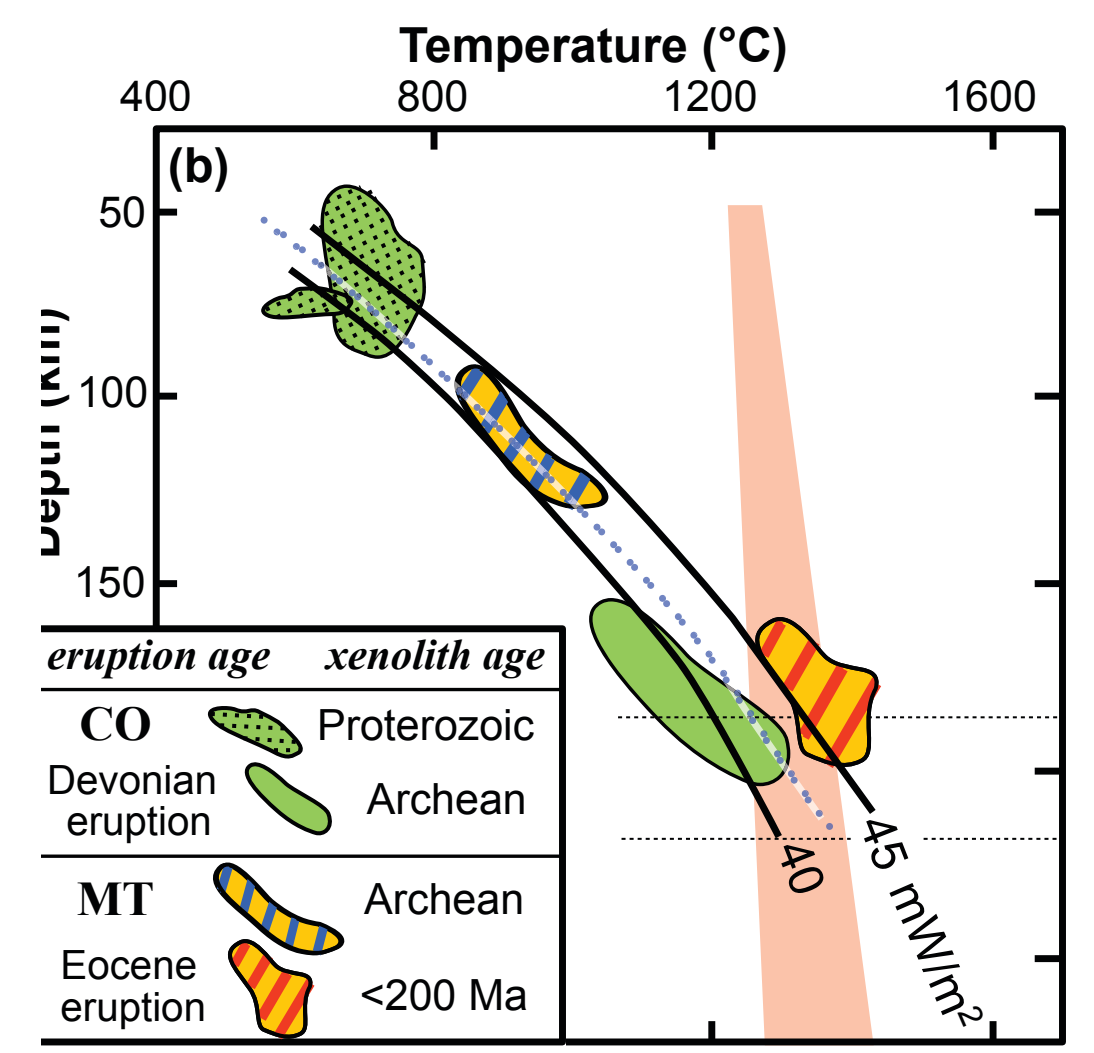


Fig. 3

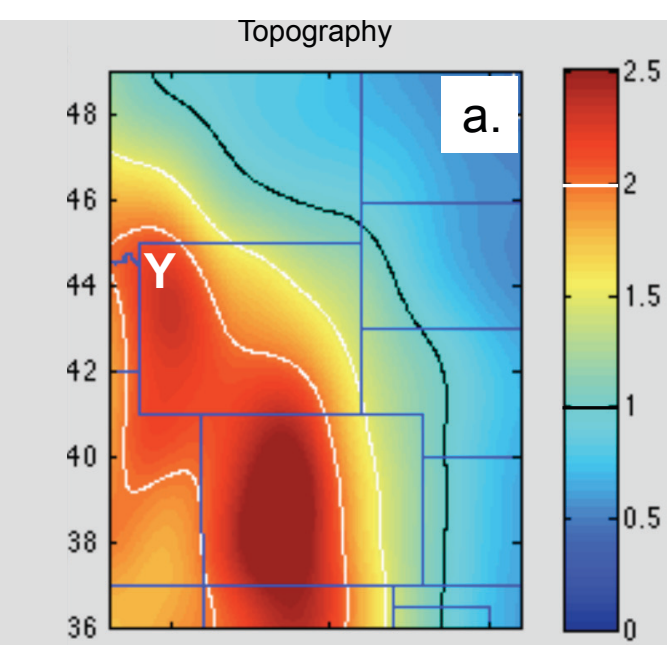

Dynamic topography (from below $200 \mathrm{~km}$ )
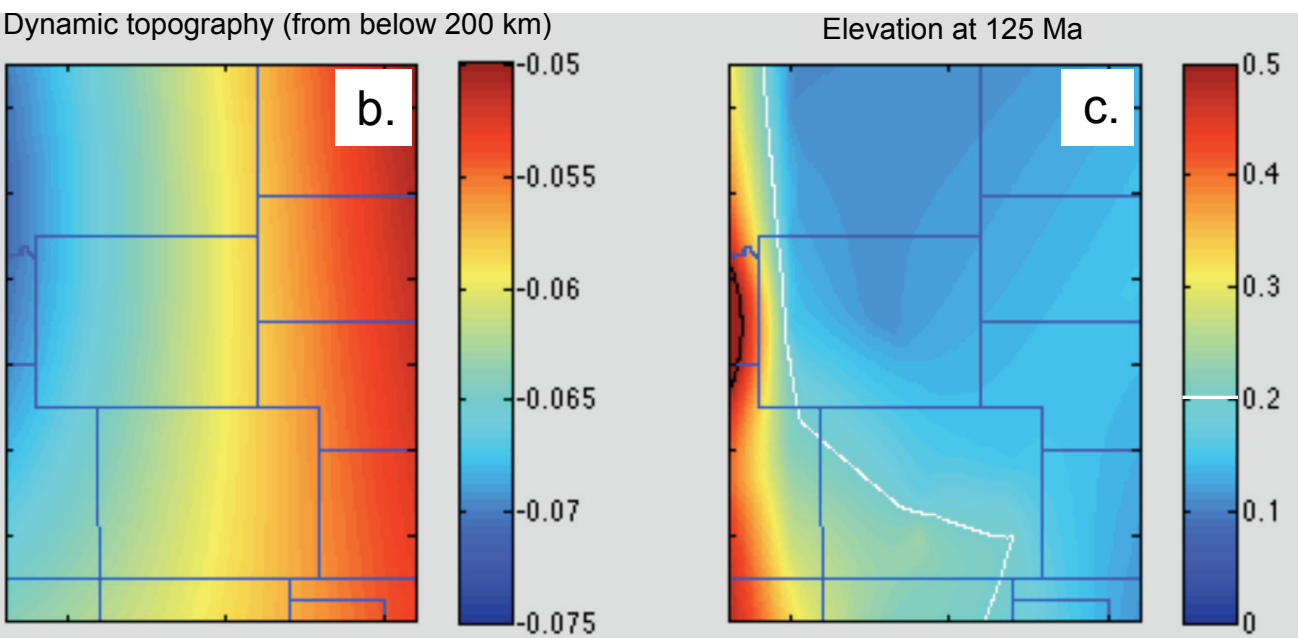

Elevation from sediment after $125 \mathrm{Ma}$

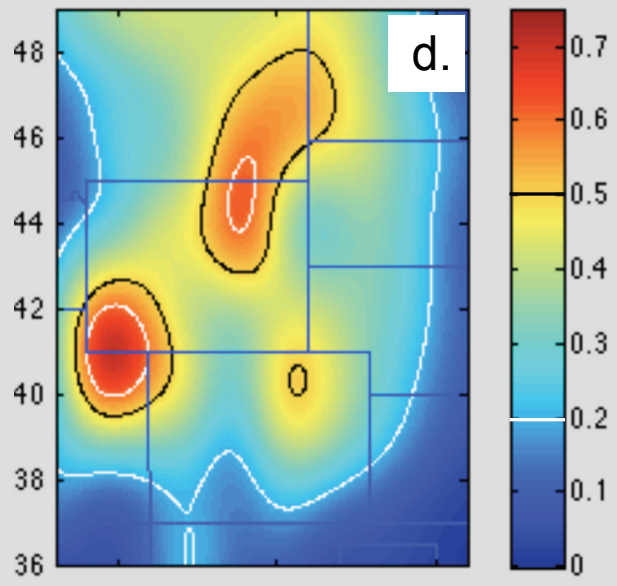

Elevation (d) and erosion

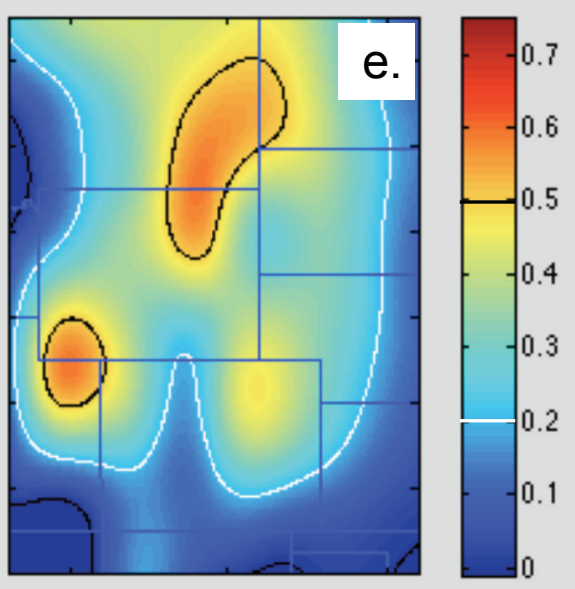

Thermal uplift (from Levandowski, et al.)

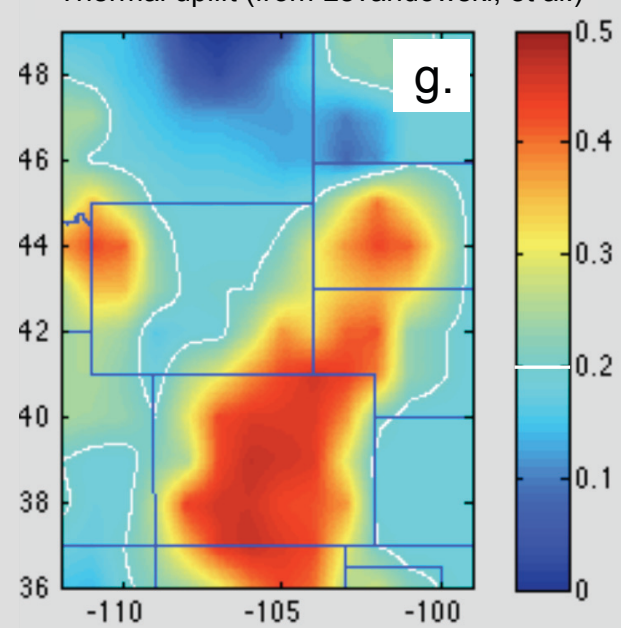

Predicted elevation from all effects

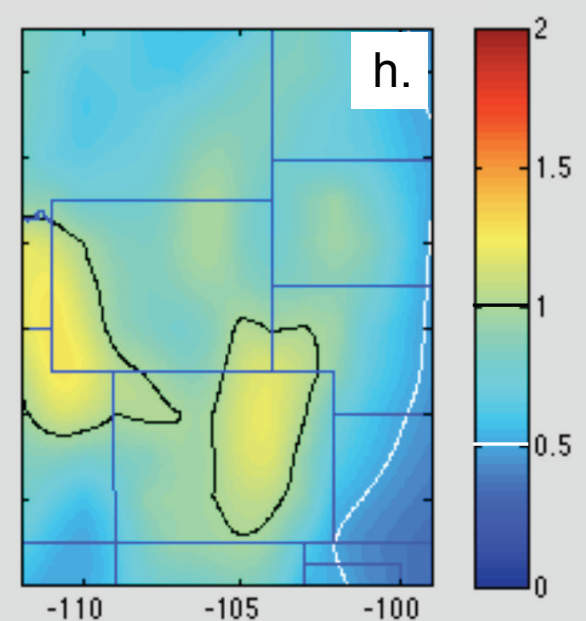

80-40 Ma crust thickening (from Bird)

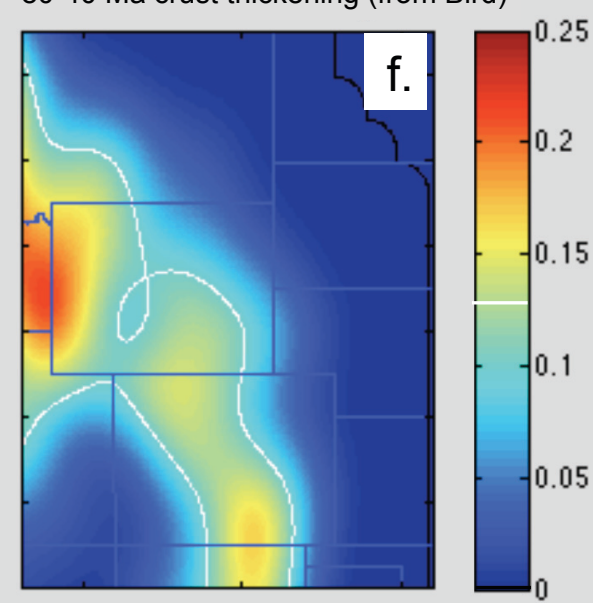

Observed - Predicted dots (Spencer), squares (Jones)

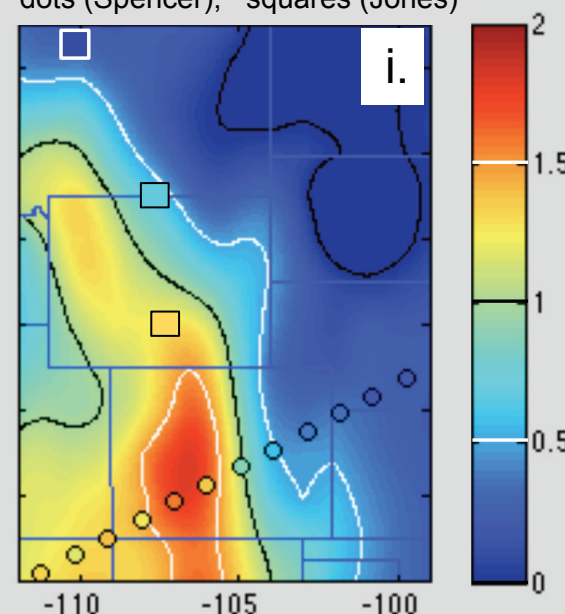




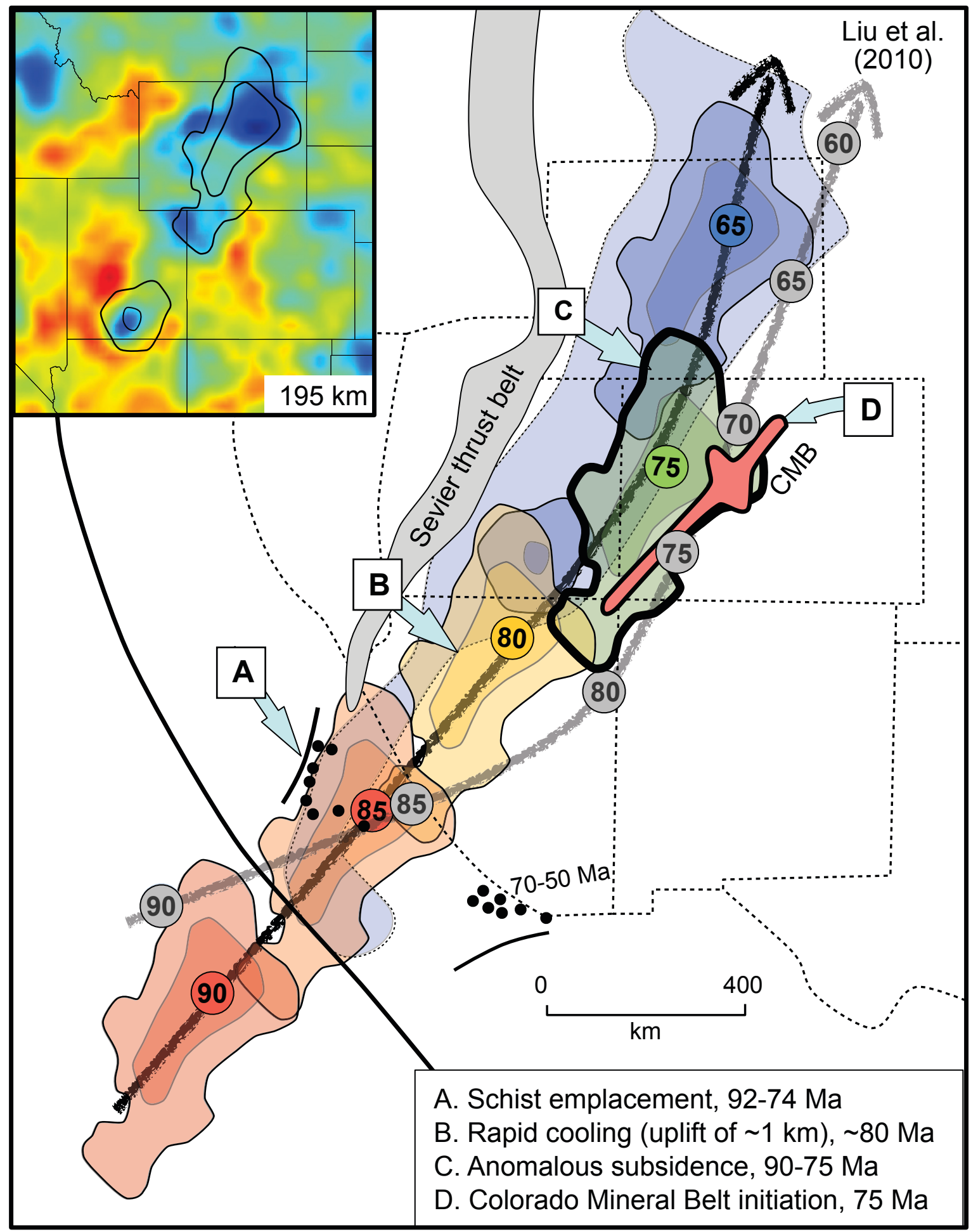


Fig 5

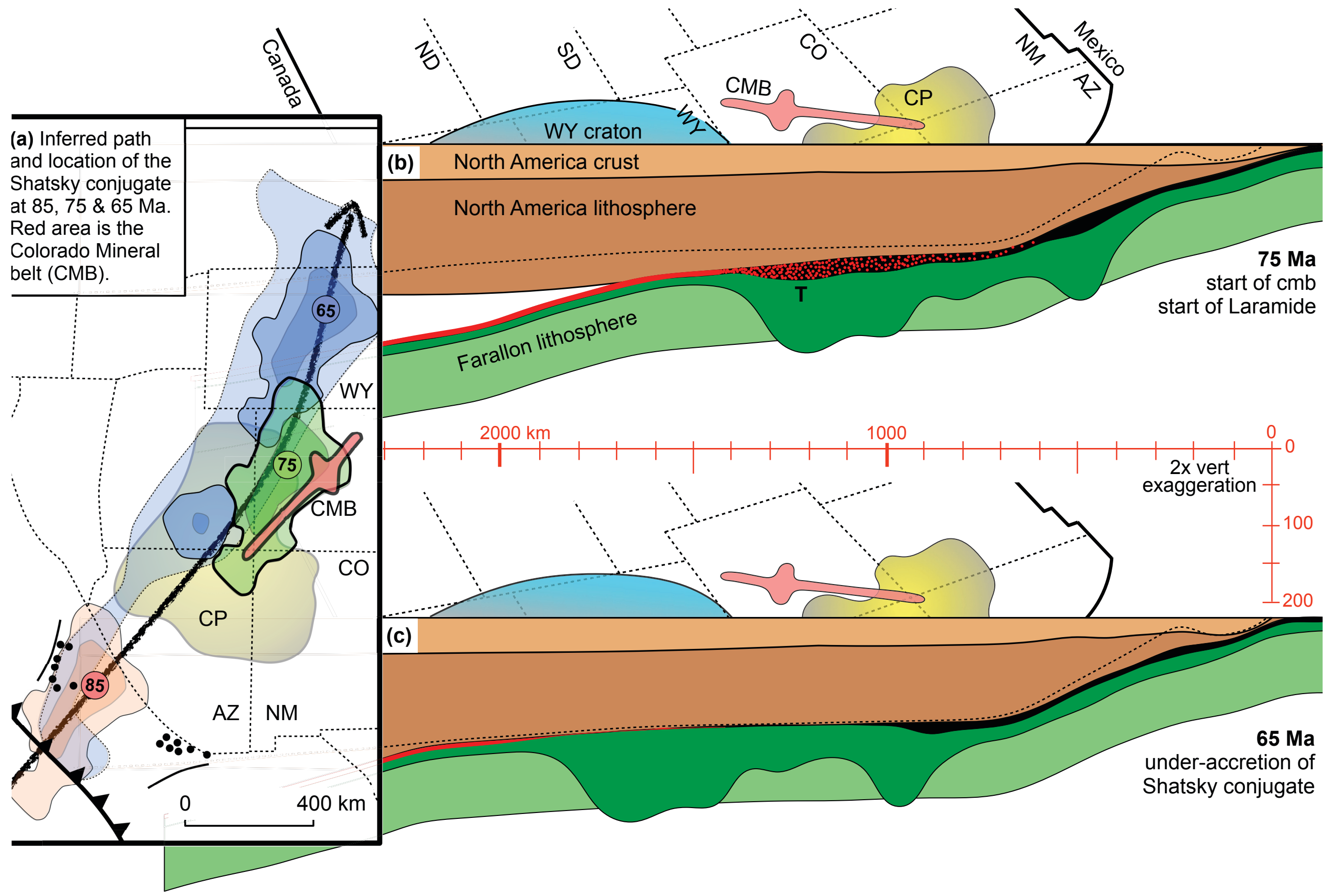

